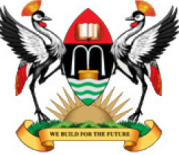

East African School of

Higher Education Studies \& Development
Makerere Journal of Higher Education

ISSN: $1816-6822 ; 4(2)(2013) 293-310$

DOI: http://dx.doi.org/10.4314/majohe.v4i2.12

(C) The Author(s) 2013

Reprints \& permission: EASHESD

http://ajol.info/majohe

\title{
Ignoring Functionality as a Correlate of the Underutilization of Computer and Information Technology in Rwandan Higher Education Institutions
}

\author{
Jude Ssempebwa ${ }^{1, *}$, F. E. K. Bakkabulindi ${ }^{2}$, Beatrice Ssekabembe ${ }^{2}$ \\ ${ }^{1}$ School of Postgraduate Studies and Research, Kampala International University \\ [*Corresponding author: spgs@ @iu.ac.ug]; ${ }^{2}$ East African Institute of Higher Education Studies \\ and Development, Makerere University
}

\begin{abstract}
The world over, higher education institutions (HEIs) have invested heavily in the promotion of computer and information technology (CIT). In many HEIs in Sub-Saharan Africa, however, a disturbing dilemma pertains to the low adoption of the technologies, in spite of the enormity of the investment that the institutions have made in their promotion. Grounded on the propositions of the Total Cost of Ownership (TCO) model, this study examined whether this dilemma is due to the way the institutions invest in the promotion of the technologies, taking the case of three HEIs in Rwanda. Data were collected on the institutions' expenditure on components of the TCO and the findings contrasted with documented experiences from CIT-savvy settings, to establish whether the institutions meet the TCO. The findings were that expenditure on the promotion of the technologies is skewed in disfavor of cost components that pertain to the functionality of the technologies. Overriding attention is put on acquisition of the technologies but this has led to underutilization of the CIT ware acquired. It was also found that the availability of CIT ware and personnel in the institutions is still inadequate, notwithstanding the bias of investment in CITs that is in favor of their acquisition. It is, therefore, concluded that while efforts to acquire CIT ware and personnel are still relevant, the managers of the institutions should also increase expenditure on training end-users; establishing end-user service desks; and repairing/replacing obsolete CIT equipment.
\end{abstract}

Keywords: TCO; ICT adoption; Rwanda.

\section{$1 \quad$ Introduction}

Computer and information technology (CIT) is an important tool in the development of higher education (Bisaso, 2006; Loing, 2005; Zhao, 2003). 
Indeed, in many instances, commitment to the development of CITs is a condition for accreditation of higher education institutions (HEIs), by relevant authorities and professional bodies (see, for example, National Council for Higher Education [NCHE], 2004). Lecturers are urged to adopt e-teaching and students are urged to adopt e-learning (see, for example, Baryamureeba, 2004). Researchers are encouraged to use e-resources in the processes of conducting their research and to publish their findings electronically. HEI managers are urged to adopt e-management systems and graduates of HEIs are expected to be computer savvy. Education that promotes the development and adoption of CITs is expected to enhance international competitiveness and, in the third world, it is hoped to surmount exclusion and, thus, promote development (Lwakabamba, 2005; Murenzi \& Hughes, 2006; Republic of Rwanda [RoR], n.d.; Rodrigo, 2005). In the more recent years, HEI league table rankings have placed significant weight to HEIs' possession, and utilization, of CITs, with some of the rankings considering only the online discoverability of the institutions' publications and volume of traffic on their websites. Over the last two decades, therefore, HEIs have invested heavily in the development of CITs (Adam, 2003; Czerniewicz \& Carr, 2005; Damonse, 2003; Farrell \& Isaacs, 2007; Loing, 2005; Muzaki \& Mugisa, 2006).

In many HEIs in Sub-Saharan Africa, however, a disturbing dilemma pertains to the low adoption of CITs, despite the enormity of the investment in their promotion (Agaba, 2003; Interuniversity Council of East Africa [IUCEA], 2002; Muyinda et al., 2009; Wakanyansi, 2002). Citing the Association of African Universities and IUCEA, for example, Adam (2003) notes that HEIs in Africa have lagged behind similar institutions in other parts of the world in embracing CITs, adding that in most of the institutions, CITs are at the periphery. Bakkabulindi et al. (2008) and Farrell (2007) affirm that this dilemma has received significant scholarly and policy attention. Notwithstanding, hitherto, investment in the promotion of the technologies has not been thoroughly examined for appropriateness and, therefore, possible correlation with the low utilization of the technologies. This is despite the fact that adoption of these technologies necessitates that investment in their promotion is done in an appropriate way, meaning that, where CIT utilization targets are not being realized, the investment should be appraised for appropriateness.

A well established fact pertaining to the efficacy of investment in the promotion of CITs is that when an institution purchases computers or installs a network of computers, the cost of acquiring the CIT facilities is only one small part of the expenses it can expect in subsequent years, if it is going to use those facilities effectively (Consortium for School Networking [CoSN], 2001). In understanding the low utilization of CITs in HEIs, therefore, there is need to 
look beyond the total cost of acquiring CIT facilities (which concerns itself only with the cost of procuring the facilities) to address the Total Cost of Ownership (TCO) - a lifecycle cost view, which includes acquisition, setup, support, ongoing maintenance, service and all operating expenses (Bhutta \& Huq, 2002; Kanagaraj \& Jawahar, 2009). In Sub-Saharan African HEIs, however, the total cost of owning CITs has not attracted attention. This is despite the fact that many of these institutions are resource constrained (Bakkabulindi, 2006; Court, 1999; Kasozi, 2003; Mayanja, 2007; Ssempebwa, 2007), meaning that fears that they do not meet the total cost of owning these technologies are not farfetched.

HEIs in Rwanda typify the low adoption of CITs that has characterized many HEIs in Sub-Saharan Africa, despite commitment to the promotion of these technologies in the institutions - in line with the country's vision to achieve middle income status by 2020 through modernizing its key sectors using CITs. Incidentally, these institutions also typify the resource constraints that characterize many HEIs in the region (Lwakabamba, 2005), which makes the fear that Sub-Saharan African HEIs do not meet the total cost of owning CITs relevant to them. Hitherto, however, the credence of this fear has not been verified. Hence, this study was conducted to verify it - to establish whether the under-utilization of CITs in the institutions is related to the way investment in the promotion of the technologies is done.

\subsection{Conceptual Underpinning}

Working with Gartner Inc., CoSN customized a TCO model highlighting the lifecycle cost components of CITs in educational institutions. Thus, they propose a framework within which the comprehensiveness, in principle adequacy, of educational institutions' investment in the promotion of CITs can be appraised. According to CoSN (2001), the cost components are: 1) hardware (expenditure on hardware); 2) retrofitting (expenditure on physical structure refurbishment, upgrading of electrical and transmission installations, air conditioning, etc.); 3) professional development (expenditure on development of end-users' capacity to use CITs); 4) software (expenditure on licenses, customization of applications, upgrades, etc.); 5) support (expenditure on maintenance of CIT facilities and end-user service desks); 6) replacement (expenditure on replacing obsolete CIT units and peripherals); and 7) connectivity (expenditure on internet and telephony subscriptions and building/ connecting to relevant computer and information networks).

This model contains two major cost categories: 1) direct costs (which are primarily concerned with the acquisition, and installation, of the CIT facilities, i.e., expenditure on hardware, software, retrofitting and connectivity); and 2) indirect costs (which are concerned with the functionality and utilization of the 
CITs, i.e., expenditure on end-users' professional development, support and replacement). According to $\operatorname{CoSN}$ (2003), the costs in the indirect category tend to be recurrent and, unless they are well attended, could be associated with losses - arising out of peer support (i.e. time spent by users asking questions of other users and time spent by users responding to other users' questions); file and data management (i.e. costs of end-users' operation of CITs); and downtime (i.e. idle time spent by users when CITs are not working).

\section{2 'CIT TCO types' Reported in Literature}

To be successful, investment in the promotion of CITs should address each of the components of the TCO (Loing (2005). Similarly, conceptualization of appraisal of investment in the promotion of these technologies in educational institutions should address itself to each of the cost components, to examine the comprehensiveness of the investment. Appraisal of the comprehensiveness of investment in CITs in a given setting necessitates standards, against which to judge the satisfactoriness of expenditure on each of the components of the total cost of owning CITs in the setting of interest. However, these standards are generally non-existent-because studies of institutions' expenditure on components of the total cost of owning CITs follow methodologies and report figures that are peculiar to the institutions (Ellram, 1995) rather than put forward a state-of-the-art (see, for example, Bakia, 2002; Coleman, 1998; and RAND Corporation, 1995 and Rothstein \& McKnight, 1996 cited by CoSN, 2001). Moreover, majority of the studies published on educational institutions' investment in CITs give the institutions' overall expenditure on CITs but without disaggregating this expenditure among the components of the TCO.

In higher education, we identified only one study (Coleman, 1998) disaggregating the expenditure of an HEI (University of Tennessee) on components of the TCO CITs (Table 1).

Table 1: Expenditure on Components of the Total Cost of Owning CITs ${ }^{*}$ at University of Tennessee (1998)

\begin{tabular}{llc}
\hline Cost Category & Component of TCO & Expenditure (\%) \\
\hline Direct Costs & Hardware \& connectivity & 21 \\
& Software & 12 \\
& Retrofitting & 14 \\
& Sub-total & 47 \\
Indirect Costs & Operations \& support & 30 \\
& End users' development & 23 \\
& Sub-total & 53 \\
\hline
\end{tabular}

*Amortized over five (5) years

Source: Coleman (1998) 
Table 1 shows that at the University of Tennessee, which Coleman (1998) characterizes as a CIT high adoption HEI, expenditure on components of the total cost of owning CITs in the direct and indirect categories tends towards parity-indicative of concern for both the acquisition and functionality of the technologies. Using qualitative attributes, CoSN (2001) also categorizes 'CIT TCO types' (Table 2).

Table 2: Attributes of 'CIT TCO Types' Identified by CoSN (2001)

\begin{tabular}{|c|c|c|c|}
\hline \multirow{2}{*}{$\begin{array}{l}\text { Component } \\
\text { of TCO }\end{array}$} & \multicolumn{3}{|c|}{ TCO Type } \\
\hline & Savvy & Doing the Best we can & $\begin{array}{l}\text { Worry about it } \\
\text { tomorrow }\end{array}$ \\
\hline $\begin{array}{l}\text { Professional } \\
\text { Development }\end{array}$ & $\begin{array}{l}\text { Devotes } 15-30 \% \text { of } \\
\text { budget to staff } \\
\text { development }\end{array}$ & $\begin{array}{l}\text { Provides some staff } \\
\text { training, but not at times } \\
\text { that are convenient or } \\
\text { when staff is ready to put } \\
\text { the lessons to work }\end{array}$ & $\begin{array}{l}\text { Assumes that end- } \\
\text { users "will learn on } \\
\text { the job" }\end{array}$ \\
\hline Support & $\begin{array}{l}\text { At least one support } \\
\text { person per } 50-70 \\
\text { computers or one person } \\
\text { for every } 500 \text { computers } \\
\text { in a closely managed } \\
\text { networked environment }\end{array}$ & $\begin{array}{l}\text { Relies on a patchwork of } \\
\text { teachers, students and } \\
\text { overworked external staff } \\
\text { to maintain network and } \\
\text { fix problems. Does not } \\
\text { track downtime }\end{array}$ & $\begin{array}{l}\text { Relies on informal } \\
\text { support }\end{array}$ \\
\hline Software & $\begin{array}{l}\text { Recognizes that the } \\
\text { greater the diversity of } \\
\text { software deployed, the } \\
\text { more the support required } \\
\& \text { provides for regular } \\
\text { upgrades }\end{array}$ & $\begin{array}{l}\text { Utilizes centralized } \\
\text { software purchasing, but } \\
\text { choice of application and } \\
\text { respective support } \\
\text { decentralized }\end{array}$ & $\begin{array}{l}\text { Expects support } \\
\text { personnel to manage } \\
\text { whatever software } \\
\text { happens to be } \\
\text { deployed }\end{array}$ \\
\hline $\begin{array}{l}\text { Replacement } \\
\text { Costs }\end{array}$ & $\begin{array}{l}\text { Budgets to replace } \\
\text { computers on a regular } \\
\text { schedule, usually } 5 \text { years }\end{array}$ & $\begin{array}{l}\text { Plans to replace } \\
\text { computers when they can } \\
\text { no longer be repaired }\end{array}$ & $\begin{array}{l}\text { Assumes that } \\
\text { computers purchased } \\
\text { will last forever }\end{array}$ \\
\hline Retrofitting & $\begin{array}{l}\text { Recognizes that some } \\
\text { buildings require } \\
\text { modifications to } \\
\text { accommodate new CITs } \\
\text { and budgets accordingly. } \\
\text { Customizes new buildings } \\
\text { to accommodate CITs }\end{array}$ & $\begin{array}{l}\text { Understands requirements } \\
\text { for electrical and other } \\
\text { infrastructure } \\
\text { improvements and } \\
\text { incorporates them when } \\
\text { funding is available }\end{array}$ & $\begin{array}{l}\text { Devises make-shift } \\
\text { connections to } \\
\text { accommodate new } \\
\text { CITs in school } \\
\text { buildings }\end{array}$ \\
\hline Connectivity & $\begin{array}{l}\text { Plans its network to } \\
\text { provide connections that } \\
\text { provide enough } \\
\text { bandwidth to manage } \\
\text { current \& future needs. }\end{array}$ & $\begin{array}{l}\text { Has the bandwidth it } \\
\text { needs, but has no plan for } \\
\text { scaling it upward as } \\
\text { demand grows }\end{array}$ & $\begin{array}{l}\text { Satisfied with the } \\
\text { basic minimum }\end{array}$ \\
\hline
\end{tabular}


Though Coleman (1998)'s pubdate is relatively old and CoSN (2001) addresses K12 School Districts, their proposition that educational institutions' investment in the direct and indirect components of the total cost of owning CITs should tend towards parity has been endorsed by subsequent publications on investment in CITs in educational institutions (e.g. Scrimshaw, 2002; Trucano, 2005; West \& Daigle, 2004). Therefore, our study accepts Coleman (1998) and CoSN (2001) as a valid point of reference in appraising the comprehensiveness of HEIs' expenditure on components of the total cost of owning CITs, especially when it is taken into account that the more recent studies (i.e. Scrimshaw, 2002; Trucano, 2005; West \& Daigle, 2004; Lamb, Welford. \& Zirojevic, 2001) do not provide disaggregated data on institutions' expenditure on components of the TCO CITs.

\subsection{Knowledge Gap}

In Rwanda, research and commentary on impediments to the utilization of CITs in HEIs has not delved into the 'TCO type' of the institutions as a possible reason for the low adoption of the technologies. Review of related literature (e.g. Agaba, 2003; Adeya \& Oyelaran, 2002; Farrell, 2007; Farrell \& Isaacs, 2007; IUCEA, 2002; Longwe \& Rulinda, 2005; Lwakabamba, 2005; Nakaye, 1998; Niwe, 2000) indicates that, rather, surveys have primarily focused on highlighting the low utilization of the technologies, giving little attention to the factors underlying the anomaly. Moreover, even in the few instances in which the factors influencing the utilization of the technologies are addressed (e.g. Bakkabulindi et al., 2008; Farrell, 2007; Male \& Ssekabembe, 2009), they are not addressed from an investment perspective, with the result that conclusions that have implications for investment in the promotion of the technologies are inexplicit. Besides, these studies address but a few of the components of the total cost of owning CITs.

This study was conducted to fill these gaps. Conceived from the conceptual viewpoint of CoSN (2001)'s TCO model, the study undertook to: 1) examine the expenditure of Rwandan HEIs on each of the components of the total cost of owning a functional CIT network; 2) establish whether the institutions meet the total cost of owning these technologies; and 3) generate insight into the relationship between the way the institutions invest in the promotion of the technologies and the low utilization of the latter, if any. 


\section{$2 \quad$ Method}

\subsection{Selection of Institutions}

Data were collected from three HEIs in Rwanda. These were purposely selected from a target population of seven institutions that were stratified according to academic specialization (i.e. arts/humanities and science/technology); and nature of proprietorship (i.e. private and government owned). The selection was based on the longevity of the institutions' investment in the promotion of CITs and maintenance of CIT investment related records. The institutions are located in Kigali and offer both arts/humanities and science/technology study programs. Two of them are government owned while the third is privately owned.

\subsection{Participants and Selection Techniques}

The study involved 303 participants who included three procurement officers (one from each of the institutions); three heads of CIT departments (one from each of the institutions); and 297 CIT end-users. The procurement officers and heads of CIT sections were purposely involved in the study because they were best suited to provide information on their institutions' investment in CITs and the quality of these technologies at their institutions respectively. Random samples of 100 CIT end-users were also selected from each of the institutions. These were stratified by designation in the institution, gender and, in the students' category, area of academic specialization (Table 3).

Table 3: Distribution of CIT End-users

\begin{tabular}{lllr}
\hline Variable & Categories & $\mathbf{n}$ & $\mathbf{\%}$ \\
\hline Designation & Student & 164 & 55 \\
& Academic staff & 73 & 25 \\
& Administrative staff & 60 & 20 \\
Gender & Total & 297 & 100 \\
& Male & 187 & 63 \\
Specialization & Female & 110 & 37 \\
& Total & 297 & 100 \\
& Arts/humanities & 98 & 60 \\
& Science/technology & 66 & 40 \\
& Total & 164 & 100 \\
\hline
\end{tabular}

Involvement of the categories of respondents shown in Table 3 suggests that the views/experiences of all the relevant categories in the (CIT end-user) 
population were represented. In the CIT end-users' category, participants that did not respond were replaced. However, responses of three of the CIT endusers were left out of the analysis, because they were not complete.

\subsection{Instruments, Data Collection and Analysis}

Data were collected using three questionnaires. The first, which elicited data on expenditure on the promotion of CITs over five years, was administered to the procurement officers. Based on CoSN (2001), the instrument was constructed in form of a table, with rows giving the components of the total cost of owning CITs (i.e. hardware, retrofitting, professional development, software, support, replacement and connectivity) and columns giving the five years on which data on expenditure on the promotion of CITs in the institutions were collected (Table 4).

Table 4: Checklist for Compilation of Data on Expenditure on Components of Total Cost of Owning CITs

\begin{tabular}{lllllll}
\hline \multirow{2}{*}{ Cost component } & \multicolumn{5}{c}{ Year in CIT investment life cycle } \\
\cline { 2 - 5 } & 1st & 2nd & 3rd & 4th & 5th \\
\hline 1. Hardware \& connectivity & & & - & - & & \\
2. Software & - & - & - & - & - \\
3. Retrofitting & - & - & - & - & - \\
4. Operations \& support & - & - & - & - & - & - \\
5. End users' development & & & - & & - & - \\
\hline
\end{tabular}

Accordingly, the procurement officers culled figures on expenditures on each of the components of the total cost of owning CITs for each of the years from the respective (procurement) records and entered the figures into the table. These data generated a flow of expenditure on each of the components of the total cost of owning CITs for the five years. These expenditures were adjusted to be time equivalent, using the Net Present Value (NPV) method, at the corresponding bank rate (0.2), which was done using an NPV calculator. Thereafter, expenditure on each of the components of the TCO was expressed as a percentage of the total expenditure on the promotion of CITs over the years, to highlight the foci of investment into the promotion of CITs. The second questionnaire, which elicited data on the state and effectiveness of the CIT networks in the institutions, was administered to the CIT personnel. This instrument enquired into the ratio of CIT support staff to end-users; software management; downtime management; CIT end-user training; CIT equipment repairs; and the availability and quality of CIT facilities in the institutions.

To gain further insight into the effectiveness of the CIT networks, end-users' utilization of the CIT facilities and their satisfaction with the facilities were 
surveyed. This was done using the third questionnaire. This instrument had two sections, a) utilization of CIT facilities-with three questions, on rate of use of CITs, dependence on peers for CIT support and involvement in CIT selftraining (Cronbach's alpha=.82); and $b$ ) satisfaction with CIT facilities-with five questions, on the satisfactoriness of the quantity, quality and reliability of CIT facilities as well as CIT proficiency possessed and support received from CIT staff (Cronbach's alpha=.76). The instruments were assumed to be valid because they were customized from instruments that had already been validated by past studies on the total cost of owning CIT networks. Likert scale options (i.e. "Very high", "Somewhat high", "Somewhat low" and "Very low", for utilization of CITs; and "Very satisfactory", "Somewhat satisfactory", "Somewhat dissatisfactory" and "Very dissatisfactory", for satisfaction with the quality of CITs) were provided to the respondents-to make a choice on each of the attributes of utilization of and satisfaction with CITs investigated. The data obtained were entered, by 'Likert scale option'. Subsequently, the number, and percentage, of respondents choosing each of the options was obtained - to generate insight into the utilization of CITs and satisfaction with them.

Utilization of three computer laboratories (one from each of the institutions) was also observed for a teaching week (i.e. Monday to Friday), to triangulate the findings from the survey. The laboratories were purposely selected because, in each of the institutions, they were the most illustrious CIT hubs, suggesting that end-user experiences observed from them could be validly generalized to the institutions in triangulating the results of the CIT end-user satisfaction survey. The observation was non-participant but the CIT-end-users were not informed that their utilization of CITs was being observed. The observers paid attention to the adequacy and quality of CIT ware; availability of support to CIT end-users; and downtime. The observations made were recorded on a semi-structured observation checklist. The laboratories were open (to users) for at least three sessions (i.e. "Morning", "Afternoon" and "Evening"). Each day, the observers were stationed in the laboratories for two out of the three sessions. Therefore, thirty observation sessions were conducted and all the sessions for which the laboratories were open to users were represented.

\subsection{Limitations}

Data were collected from three HEIs drawn out of a target population of seven. Though the sample was taken to be satisfactorily representative, readers should note that, for a number of reasons, the experiences of individual institutions may differ. In addition, data on utilization of and satisfaction with CIT facilities and support were analyzed aggregately-because the authors were interested in a global picture on utilization of and satisfaction with CIT facilities in the 
institutions. However, readers should note that the experiences of the different institutions and categories of respondents in the sample may differ. Therefore, generalization of the conclusions of the study should be judicious.

\section{$3 \quad$ Results}

\subsection{Expenditure on Components of the TCO in Rwandan Higher Education}

The findings on the institutions' expenditure on the various components of the total cost of owning CITs (i.e. hardware and connectivity; software; retrofitting; operations and support; and end users' development) are summarized in Figure 1 .

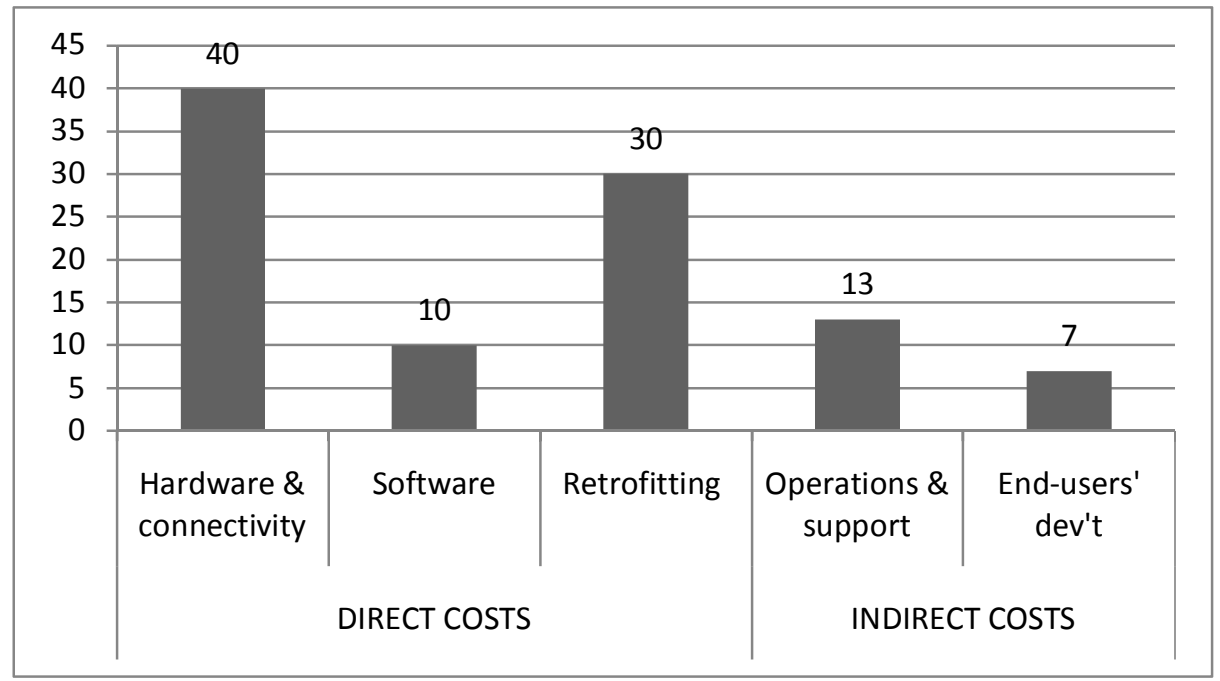

Figure 1: Expenditure on Components of the Total Cost of Owning CITs in Rwandan HEIs $(\%)$

Expenditure on the acquisition of hardware, which included expenses on connectivity, accounted for the largest proportion of the institutions' expenditure (40\%) followed by retrofitting (30\%) and operations and support (13\%). Figure 2 contrasts the distribution of the institutions' expenditure on "direct" and "indirect" components of the TCO and that of the University of Tennessee (a CIT high adoption HEI). 


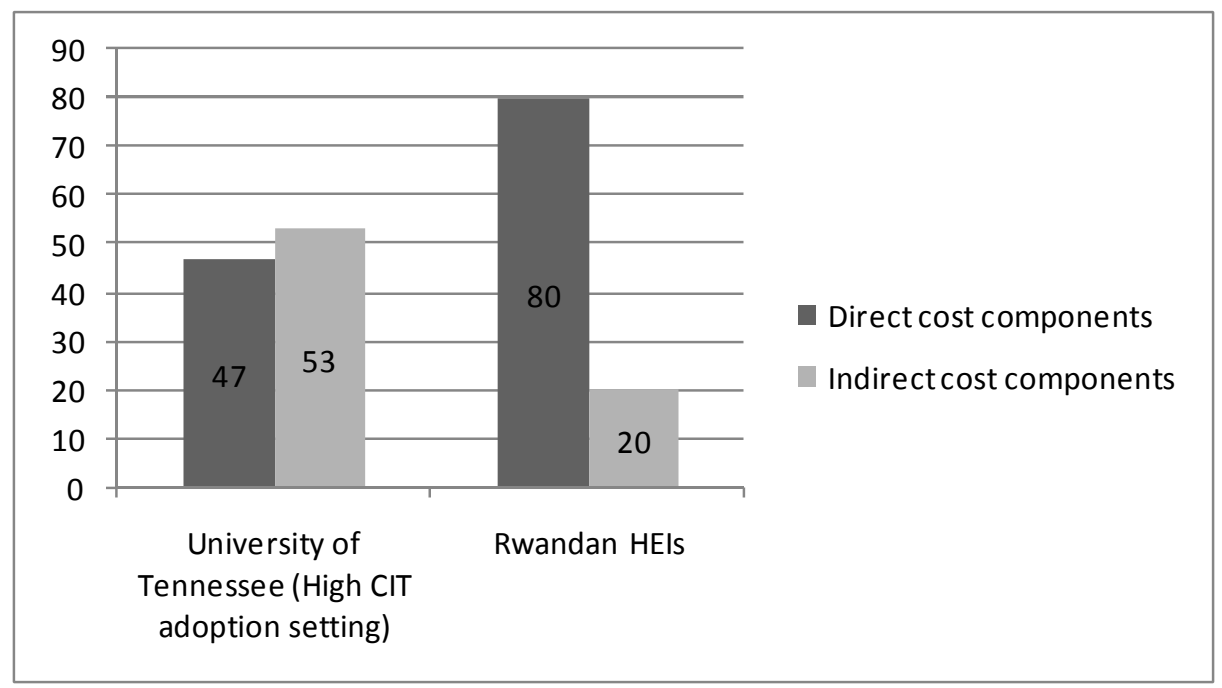

Figure 2: Expenditure on CIT Cost Components in Rwandan HEIs and a High CIT adoption HEI (\%)

Source: Figure 1 \& Coleman (1998).

Figure 2 shows that, in the Rwandan HEIs, expenditure on the promotion of CITs were skewed in favor of components of the TCO in the direct category (80\%), unlike the case in the high CIT adoption setting. End-user support was established at an average of one CIT technical person per 600 users, notwithstanding the finding that the cost component accounted for $13 \%$ of the TCO. Expenditure on software was established at $10 \%$. However, the data elicited from the CIT personnel indicated that, often, expenditure on the procurement of software is one-off. The CIT personnel also revealed that the institutions neither had instruments for measuring end-users' CIT proficiency nor regular end-user training programs. They also reported that they do not compute the opportunity cost of end-users' operations and downtime. These findings corroborated the data elicited from the CIT end-user survey (Table 5).

Table 5 shows that majority (78\%) of the CIT end-users indicated that their institutions' CIT networks were "somewhat dissatisfactory". In accounting for this "dissatisfaction", these respondents cited obsolescence/breakdown of equipment $(35 \%)$ and outages of electricity and networks (43\%), both of which were corroborated by the findings from observation of the utilization of CITs at the institutions. Indeed, majority (49\%) of the CIT end-users reported that the reliability of their institutions' CITs is "somewhat dissatisfactory" and another $14 \%$ of them rated it "very dissatisfactory" (Table 5). The finding that breakdown of CIT facilities affected the users was affirmed by the finding, from the CIT personnel, that equipment repair took an average of 14 days. 
Table 5: Utilization and Satisfactoriness of CIT Facilities (\%, $\mathrm{n}=297)$

\begin{tabular}{|c|c|c|c|c|}
\hline \multicolumn{5}{|c|}{ Utilization of CIT facilities } \\
\hline Attribute & Very high & $\begin{array}{l}\text { Somewhat } \\
\text { high }\end{array}$ & Somewhat low & Very low \\
\hline $\begin{array}{l}\text { Utilization of } \\
\text { CITs }\end{array}$ & 13 & 41 & 26 & 20 \\
\hline $\begin{array}{l}\text { Dependence on } \\
\text { peer support }\end{array}$ & 19 & 52 & 22 & 7 \\
\hline $\begin{array}{l}\text { Involvement in } \\
\text { self-training }\end{array}$ & 23 & 66 & 8 & 3 \\
\hline \multicolumn{5}{|c|}{ Satisfaction with CITs } \\
\hline Attribute & $\begin{array}{c}\text { Very } \\
\text { satisfactory }\end{array}$ & $\begin{array}{l}\text { Somewhat } \\
\text { satisfactory }\end{array}$ & $\begin{array}{c}\text { Somewhat } \\
\text { dissatisfactory }\end{array}$ & $\begin{array}{c}\text { Very } \\
\text { dissatisfactory }\end{array}$ \\
\hline Quantity of CITs & 18 & 33 & 33 & 16 \\
\hline Quality of CITs & - & 10 & 78 & 12 \\
\hline $\begin{array}{l}\text { Reliability of } \\
\text { CITs }\end{array}$ & 11 & 26 & 49 & 14 \\
\hline CIT proficiency & 15 & 47 & 29 & 9 \\
\hline $\begin{array}{l}\text { Support received } \\
\text { from CIT staff }\end{array}$ & 7 & 22 & 50 & 21 \\
\hline
\end{tabular}

Indicating that their involvement in CIT self-training is "somewhat high", majority (66\%) of the CIT end-users affirmed that they expend time on CIT system related tasks, including self training. Indeed, observation of the utilization of CITs indicated that there is heavy reliance on CIT savvy peers.

\section{Discussion}

\subsection{Do Rwandan HEIs Meet the TCO? Difference between Our Findings and 'CIT-Savvy' Settings in Literature}

Figure 1 indicates that there was a big disparity between expenditure on components of the total cost of owning CITs in the direct and indirect cost categories, unlike the case in the "CIT total cost of ownership savvy" settings identified from the literature (Figure 2). Even if it accounted for $13 \%$ of the TCO, end-user support was established at an average of one CIT technical person per 600 users-100 users above the standard in a "CIT TCO savvy" setting (Table 2). The finding that the procurement of software is one-off is in contrast to the suggestion that, in a "CIT total cost of ownership savvy setting", provisions are made for regular upgrading of software packages (Table 2). The 
CIT personnel's revelation that the institutions neither had instruments for measuring end-users' CIT proficiency nor regular end-user training programs suggests a presumption that CIT end-users "will learn on the job", typical of the "Worry about it Tomorrow" CIT TCO type characterized by CoSN (2001, p. 6) (Table 2). In addition, the finding that majority (78\%) of the end-users indicated that their institutions' CIT networks were "somewhat dissatisfactory" (Table 5) is despite the view that the quality of CITs is to be measured by the degree to which they satisfy their users (Chin \& Marcolin, 2001; Gichoya, 2005; White, 2001).

Accordingly, the study points to inadequacies in the institutions' expenditure on components of the total cost of owning CITs. "Obsolescence" points to inadequacies in replacement of CIT ware while "breakdown" points to inadequacies in CIT network and equipment repair, especially when it is taken into account that, in CIT savvy settings, there are budgets to replace equipment on a regular basis (Table 2) and equipment repair takes a few hours (International Data Corporation, 1997).

The finding that end-users relied on their peers and indulged in self-training suggests that the CIT support personnel in the institutions do not provide sufficient support. In this regard, the institutions typify the "worry about it tomorrow" CIT TCO type (Table 2), which appears to bring their commitment to the promotion of CITs to question. Particularly notable, is their relatively low expenditure on CIT cost components in the indirect category, despite the fact that these components pertain to the functionality of the technologies. This appears to account for the $26 \%$ and $20 \%$ of the respondents who respectively ranked their utilization of CITs as "Somewhat Low" and "Very Low" (Table 5). On the other hand, the finding that none of the institutions computed the opportunity cost of underinvestment in components of the TCO that relate to functionality appears to categorize the institutions among the "Doing the Best we Can" CIT TCO type, where institutions do not track CIT system outage and downtime (Table 2).

\subsection{Why do the HEIs Surveyed Ignore Functionality?}

Our findings point to some reasons as to why investment in the promotion of CITs in Rwandan HEIs is skewed in disfavor of components of the TCO that relate to the functionality of the technologies. First, it was found that there isn't enough, let alone satisfactorily qualitative, CIT ware in the institutions yet (Table 5), notwithstanding the bias of expenditure towards its acquisition (Figure 1). Since acquisition precedes functionality, the inadequacy of CIT ware appears to justify higher expenditure on hardware and connectivity. Second, retrofitting comprised an inevitable part of acquisition, since the institutions occupy structures that were not necessarily designed to support 
CITs. Third, the study indicated that the institutions did not compute the cost of end-users' CIT operations, peer support and CIT system downtime. Thus, this cost is covert and, therefore, easy to ignore yet hardware, connections and retrofitting are explicit, which makes need for them less objectionable. Fourth, the finding that the institutions did not systematically inquire into end-users' CIT utilization proficiency and training needs appears to explain the tendency to place overriding attention on acquisition of CIT facilities. Apparently, the institutions hope that, once available, CIT facilities would be utilized effectively, typical of the "worry about it tomorrow" TCO type (CoSN, 2001, p.6) where it is assumed that "CIT end-users will learn on the job." However, this assumption is contradicted by the finding that only $15 \%$ of the CIT endusers surveyed rated their CIT utilization proficiency as "very satisfactory" (Table 5).

It may be useful to note that similar findings have been made about investment in the promotion of CITs in other educational settings (see, for example, Bakia, 2002; CoSN, 2001). It may also be noted that in some settings, standards for investment in the promotion of CITs have been set primarily for cost components in the direct category, indicative of overriding focus on acquisition. In Uganda, for example, the National Council for Higher Education (the agency responsible for quality assurance in the country's higher education) outlines standards for student-computer ratios, possession of a website and connectivity to the internet but without paying any attention to their functionality (NCHE, 2004).

However, in some of these settings, attention is increasingly being paid to the need to meet or avoid CIT cost components in the indirect category. According to CoSN (2001, p.11), for example, in the United States, "leaders and policy makers are recognizing that schools must devote more attention to staff development if they are to achieve their technology goals", adding that many states are requiring schools to devote a higher proportion of state provided funds to staff development and that many government and non-profit grant programs require school districts to devote a certain portion of their budgets to assessment of the efficacy of their CITs. Integration of CIT needs in the design of new buildings is also presenting opportunity for reducing expenditure on retrofitting (Zeisler, 1998), thereby freeing up resources for expenditure on other components of the TCO.

\subsection{Conclusions and Recommendations}

This study leads to the conclusion that, rather than meet the total cost of owning CITs, investment in the promotion of these technologies in Rwandan HEIs is skewed in disfavor of functionality, with the result that utilization of the CIT facilities acquired is low. It also leads to the conclusion that the institutions do 
not have satisfactory CIT facilities, notwithstanding the bias of investment in CITs in favor of their acquisition. Through disaggregating percentage budgetary allocation to components of the TCO, the study indicates that the institutions put overriding attention on acquisition of CIT facilities. Although (financial) resources constraints have been primarily blamed for the low adoption of CITs in the HEIs, the institutions could spend more of the few resources available for the promotion of CITs on cost components in the indirect category, indicative of concern for both the acquisition and functionality of the technologies. Accordingly, the study leads to the conclusion that while efforts to acquire CIT facilities are still relevant, there is need to pay attention to the functionality of these facilities. Thus, it is recommended that the managers of the institutions identify the causes of CIT system downtime and evaluate their end-users' CIT utilization proficiency-to inform the elimination of downtime and delivery of end-user training and support programs that could reduce end-users' operations and peer support. This necessitates greater budgetary allocation to end-user training; support; and replacement of obsolete CIT units and peripherals. Thus, it is recommended that education funding and regulatory agencies adopt standards for percentage expenditure on components of the total cost of owning CITs that pertain to the functionality of the technologies, as it is already being done in some settings like the United States. Finally, when considered in terms of Zeisler (1998)'s conclusion that integration of CIT needs in the design of new buildings presents opportunity for reducing expenditure on retrofitting, the finding that retrofitting accounted for $30 \%$ of the TCO implies that the institutions need to integrate CIT needs in the design of new buildings, to reduce expenditure on the cost component.

\section{References}

Adam, L. (2003). Information and communication technologies in higher education in Africa: initiatives and challenges. Journal of Higher Education in Africa, 1(1), 195-221.

Adeya, N. C., \& Oyelaran, O. B. (2002). The internet in African universities: case studies from Kenya and Nigeria. United Nations University Institute for New Technologies. Retrieved from www.infonomics.nl/globalequality/reports/IDEaf.pdf.

Bakia, M. (2002). The cost components of computers in classrooms: data from developing countries. TechKnowLogia, January-March, 63-68. Retrieved from http://www.techknowlogia.org/TKL_Articles/PDF/370.pdf. 
Bakkabulindi, F. E. K. (2006). Financing higher education in Uganda. Nkumba University Education Journal, 1(1), 42-59.

Bakkabulindi, F. E. K., Nakata, J. L., \& Amin, M. E. (2008). Organizational characteristics as correlates of ICT adoption in Makerere University. Kampala International University Research Digest, 1(2), 122-135.

Baryamureeba, V. (2004). Progress and unfinished business in creating an ICT literate campus population. Paper presented at a workshop to address ICT policy proposals at Makerere University, July 9-10, 2004, Hotel Triangle, Jinja.

Bhutta, K. S., \& Huq, F. (2002). Supplier selection problem: a comparison of the total cost of ownership and analytic hierarchy process approaches. Supply Chain Management: an International Journal, 7(3), 126-135.

Bisaso, R. (2006). Optimizing the potential of educational computing research in emerging countries. In V. Baryamureeba \& W. Ddembe (Eds.), Measuring computing research excellence and vitality (pp. 56-62). Kampala: Fountain Publishers.

Chin, W. W., \& Marcolin, B. W. (2001). The future of diffusion research. The Database for Advances in Information Systems, 32(3), 7-12.

Coleman, A. T. (1998). Lowering the Total Cost of Ownership (TCO) for the desktop. Paper presented at CAUSE98. Retrieved from http://net.educause.edu/ir/library/html/cnc9807/cnc9807.html.

CoSN. (2001). Taking TCO to the classroom: a school administrator's guide to planning for the total cost of new technology. Retrieved from http://classroomtco.cosn.org/tco2class.pdf.

CoSN. (2003). Why total cost of ownership (TCO) matters: a report and estimating tool for $k$-12 school districts. Retrieved from classroomtco.cosn.org/tco_backgrounder.pdf.

Court, D. (1999). Financing higher education in Africa: Makerere, the quite revolution. Retrieved from www.bc.edu/bc_org/avp/soe/cihe/ihec/.../FinancingHE_Africa.pdf.

Czerniewicz, L., \& Carr, T. (2005). Growing communities of practice among educational technology researchers and practitioners in developmentoriented contexts: linking local and global debates. International Journal of Education and Development using Information and Communication Technology, 1(2), 3-24.

Damonse, M. Y. (2003). Online learning: implications for effective learning for higher education in South Africa. Australian Journal of Educational Technology, 19(1), 25-45.

Ellram, L. M. (1995). Total cost of ownership: an analysis approach for purchasing. International Journal of Physical Distribution and Logistics Management, 25(8), 4-23. 
Farrell, G. (2007). Survey of ICT and education in Africa: Rwanda Country Report-ICT in education in Rwanda. Retrieved from www.infodev.org/en/document.423.aspx.

Farrell, G., \& Isaacs, S. (2007). Survey of ICT and education in Africa: a summary report based on 53 country surveys. Retrieved from http://akgul.bcc.bilkent.edu.tr/egitim/ict-africa-survey.pdf.

Gichoya, D. (2005). Factors affecting the successful implementation of ICT projects in government. The Electronic Journal of e-Government, 3(4), 175184.

International Data Corporation (1997). Understanding the total cost and value of integrating technology in schools: an IDC white paper sponsored by Apple Computer, Inc. Retrieved from http://www.apple.com/education/k12/leadership/LSWTF/IDC1.html.

IUCEA. (2002). Information and ICT requirements analysis at selected universities in East Africa. Kampala: Author.

Kanagaraj, G., \& Jawahar, N. (2009). A simulated annealing algorithm for optimal supplier selection using the reliability-based total cost of ownership model. International Journal of Procurement Management, 2(3), 244-266.

Kasozi, A. B. K. (2003). University education in Uganda: challenges and opportunities for reform. Kampala: Fountain Publishers.

Loing, B. (2005). ICT and higher education: $9^{\text {th }}$ UNESCO/NGO higher education collective consultation on higher education, April 6-8, 2005. Retrieved from http://www.unesco.org/ngo/comite/cpmother/enseign-sup/ticgb.pdf.

Longwe, B., \& Rulinda, C. (2005). Of gateways and gatekeepers: the history of internet exchange points in Kenya and Rwanda. In F. E. Etta \& L. Elder (Eds.), At the crossroads: ICT policy making in East Africa (pp. 199-212). Nairobi: East African Educational Publishers.

Lwakabamba, S. (2005). The development of ICTs in Rwanda: pioneering experiences. In F.E. Etta \& L. Elder (Eds.), At the crossroads: ICT policy making in East Africa (pp. 213-224). Nairobi: East African Educational Publishers.

Male, J., \& Ssekabembe, B. (2009). Information and communication technology (ICT) and adult learning: a case of graduate students at Makerere University. Makerere Journal of Higher Education, 2(1), 143-154.

Mayanja, M. K. (2007). Improving income from internally generated funds without provoking students or staff strikes at Makerere and other universities. Uganda Higher Education Review, 4(2), 2-8.

Murenzi, R., \& Hughes, M. (2006). Building a prosperous global knowledge economy in Africa: Rwanda as a case study. International Journal of Technology and Globalization, 2(3), 252-267. 
Muyinda, P. B., Lubega, J. T., \& Lynch, K. (2009). A model for scaffolding traditional distance learners in Africa for constructivist online learning. Makerere Journal of Higher Education, 2(1), 155-176.

Muzaki, F., \& Mugisa, E. (2006). Towards enhancing learning with information and communication technology in universities. In V. Baryamureeba \& W. Ddembe (Eds.), Measuring computing research excellence and vitality (pp. 15-25). Kampala: Fountain Publishers.

NCHE. (2004). Checklist of institutional capacity indicators for the accreditation of institutions and programs. Kampala: Author.

Rodrigo, M. M. T. (2005). Quantifying the divide: a comparison of ICT usage of schools in Metro Manila and IEA-surveyed countries. International Journal of Educational Development, 25(1), 53-68.

RoR. (n.d.). ICT in education policy (draft). Retrieved from http://rwanda.glp.net/c/document_library/get_file?folderId=407838\&name= DLFE-12473.pdf.

Scrimshaw, P. (2002). Total cost of ownership: A review of the literature. ICT in Schools Research and Evaluation Series - No.6. London: Becta.

Ssempebwa, J. (2007). Funding higher education in Uganda: a case for the liberalization of fees. Kampala International University Research Digest, 1(1), 44-59.

Trucano, M. (2005). Knowledge Maps: ICT in Education. Washington, DC: infoDev / World Bank. Retrieved from http://www.infodev.org/en/Publication.8.html.

West, R., Daigle, S. L. (2004). Total cost of ownership: a strategic tool for ERP planning and implementation. Colorado: EDUCAUSE.

White, S. (2001). Quality assurance and learning technologies: intersection agendas in UK higher education. Quality Assurance in Education, 8(1), 7-16.

Zeisler, A. (1998). Determination of potential cost savings that could result from a systems approach to school facility design and technology specification. Paper presented at the Grants and Funding for Technology Conference. Retrieved from http://www.schoolwire.org.

Zhao, F. (2003). Enhancing the quality of online higher education through measurement. Quality Assurance in Education, 11(4), 214-221. 